\title{
Nitrogen and phosphorus recycling mediated by copepods and response of bacterioplankton community from three contrasting areas in the western tropical South Pacific $\left(20^{\circ} \mathrm{S}\right)$
}

\author{
Valentina Valdés $^{1,2}$, François Carlotti ${ }^{3}$, Ruben Escribano ${ }^{4,5}$, Katty Donoso $^{3}$, Marc Pagano $^{3}$, Verónica Molina ${ }^{6}$, and \\ Camila Fernandez ${ }^{2,7,8}$ \\ ${ }^{1}$ Programa de Doctorado en Oceanografía, Departamento de Oceanografía, Facultad de Ciencias Naturales y Oceanográficas, \\ Universidad de Concepción, Concepción, Chile \\ ${ }^{2}$ Sorbonne Université, UPMC Univ Paris 06, Laboratoire d'Océanographie Microbienne (LOMIC), Observatoire \\ Océanologique de Banyuls/Mer, 66650, Banyuls/Mer, France \\ ${ }^{3}$ Aix-Marseille Univ, Universite de Toulon, CNRS, IRD, OSU PYTHEAS, Mediterranean Institute of Oceanography MIO, \\ UM 110, 13288, Marseille, Cedex 09, France \\ ${ }^{4}$ Departamento de Oceanografía, Universidad de Concepción, Concepción, Chile \\ ${ }^{5}$ Instituto Milenio de Oceanografía, Universidad de Concepción, Concepción, Chile \\ ${ }^{6}$ Departamento de Biología and Programa de Biodiversidad, Facultad de Ciencias Naturales y Exactas, Universidad de Playa \\ Ancha, Playa Ancha, Valparaíso, Chile \\ ${ }^{7}$ FONDAP INCAR center (15110027), and PFB-31 COPAS Sur Austral Program, Departamento de Oceanografía, \\ Universidad de Concepción, Concepción, Chile \\ ${ }^{8}$ Centro FONDAP de Investigación en Dinámica de Ecosistemas Marinos de Altas Latitudes (IDEAL), Valdivia, Chile
}

Correspondence: Valentina Valdés (vvaldesc@udec.cl)

Received: 28 December 2017 - Discussion started: 25 January 2018

Revised: 5 July 2018 - Accepted: 28 August 2018 - Published: 15 October 2018

\begin{abstract}
Zooplankton play a key role in the regeneration of nitrogen and phosphorus in the ocean through grazing and metabolism. This study investigates the role of the organic and inorganic nitrogen and phosphorus compounds released by copepods on biogeochemical processes and on the microbial community composition during the OUTPACE cruise (18 February-3 April 2015) at three longduration stations (LD). Two LD stations were located in the Melanesian Archipelago region (MA; LD A and LD B) and one in the South Pacific Gyre (SG; LD C), which represent oligotrophic and ultra-oligotrophic regions respectively. At each station, on-board microcosm experiments were performed with locally sampled organisms, comprising a mix of epipelagic copepods fed with their natural food and then incubated along with wild microbial assemblages. In the presence of copepods, ammonium and dissolved organic nitrogen showed a significant increase compared to a control in two situations: in ammonium concentration (rate: $0.29 \mu \mathrm{mol} \mathrm{L}^{-1} \mathrm{~h}^{-1}$ after $4 \mathrm{~h}$ of incubation) in
\end{abstract}

LD $\mathrm{C}$ and in dissolved organic nitrogen concentration (rate: $2.13 \mu \mathrm{mol} \mathrm{L}^{-1} \mathrm{~h}^{-1}$ after $0.5 \mathrm{~h}$ of incubation) in LD A. In addition, during the three experiments, an enhanced remineralization (ammonification and nitrification) was observed when adding copepods compared to the controls. A shift in the composition of the active bacterial community was observed for the experiments in LD A and LD B, which were mainly characterized by an increase in Alteromonadales and SAR11, respectively, and linked with changes in nutrient concentrations. In the experiment performed in LD C, both groups increased but at different periods of incubation. Alteromonadales increased between 1 and $2 \mathrm{~h}$ after the beginning of the experiment, and SAR 11 at the end of incubation. Our results in near in situ conditions show that copepods can be a source of organic and inorganic compounds for bacterial communities, which respond to excretion pulses at different timescales, depending on the initial environmental conditions and on their community composition. These processes can significantly contribute to nutrient recycling and regenerated 
production in the photic zone of ultra-oligotrophic and oligotrophic oceanic regions.

\section{Introduction}

The tropical South Pacific is considered one of the most oligotrophic regions in the world ocean. Its biogeochemical characteristics include nitrogen and phosphate limitations, which modulate the low biological productivity (Moutin et al., 2008). In addition, the strong thermal stratification, enhanced by current global warming, decreases the nutrient supply to the euphotic zone (Polovina et al., 2008). The western tropical South Pacific (WTSP) was recently recognized as a hotspot of $\mathrm{N}_{2}$ fixation (Bonnet et al., 2017) and the input of new nitrogen to the surface ocean through this process sustains over $50 \%$ of the primary productivity (Karl et al., 1997; Carpenter et al., 2004). However, it has been reported that predator-prey interactions can provide substantial amounts of nitrogen and phosphorus, and supply an alternative substrate for phytoplankton and heterotrophic microorganisms, stimulating the microbial loop in a variety of areas and contributing to the regenerated and new production (Richardot et al., 2001; Vargas et al., 2007; Arístegui et al., 2014; Valdés et al., 2017a, b).

Metazooplankton metabolism is recognized as one of the main mechanisms controlling concentration, composition and cycling of dissolved organic matter (DOM) in the sea (Sipler and Bronk, 2014). Zooplankton may release dissolved organic and inorganic matter through sloppy feeding (Møller, 2004, 2007), leaching of fecal pellets (Hasegawa et al., 2000; Steinberg et al., 2002) and excretion (Saba et al., 2011) and along with bacterial remineralization, it determines the amount of regenerated nitrogen and phosphorus available for phytoplankton production (Steinberg and Landry, 2017). Copepods excrete up to $53 \%$ of their body nitrogen per day, mainly in the form of ammonium, followed by urea and amino acids (Bidigare, 1983), thereby recycling much of the nitrogen in the water column (Ikeda et al., 2001; Steinberg and Saba, 2008).

The importance of ammonium excretion by mesozooplankton to primary production has been assessed in a variety of areas in the ocean, and the contribution to nitrogen requirements for phytoplankton growth mainly depends on the productivity of the area (Hernández-León et al., 2008). Reports indicate that zooplankton could sustain between 40 and $50 \%$ of the nitrogen requirements of phytoplankton in open ocean areas, as in the North Pacific central gyre (Eppley et al., 1973) and this percentage decreases in eutrophic waters, such as upwelling areas (Smith and Whitledge, 1977; PerézAragón et al., 2011). Other works indicate that diel vertical migrating zooplankton can sustain between $2 \%$ and $19 \%$ of the nitrogen requirements by phytoplankton through ammonium excretion at the oligotrophic Sargasso Sea (Steinberg et al., 2002). Furthermore, zooplankton can also excrete substantial amounts of dissolved organic nitrogen (DON), i.e., between $7 \%$ and $80 \%$ of the total dissolved nitrogen being released (Miller and Glibert, 1998; Conover and Gustavson, 1999; Steinberg et al., 2002; Steinberg and Saba, 2008; Pérez-Aragón et al., 2011). In fact, the composition and quantity of the excreted compounds are highly dependent on the type of food ingested by zooplankton (Miller and Roman, 2008; Saba et al., 2009). Even less studied than nitrogen is the phosphorus release by zooplankton. It has been reported that one-third of the phosphorus released by zooplankton (amphipods) was in the organic form (Johannes, 1964; Satomi and Pomeroy, 1965). Isla et al. (2004) estimated that mesozooplankton phosphate excretion can sustain $21.7 \%$ of phytoplankton phosphate requirements in oceanic water of the NW Iberian. Titelman et al. (2008) demonstrated that copepod feeding enhances organic phosphorus uptake by bacterial activity in a phosphorus-limited system. However, the impact of zooplankton metabolism on the phosphorus recycling in oceanic areas is largely unknown.

The importance of quality and quantity of DOM in structuring bacterioplankton community has been increasingly reported (Alonso-Saez and Gasol, 2007). However, the processes and mechanisms through which nitrogen and phosphorus compounds released by zooplankton can determine and influence the food web and the structure of the microbial community are unclear. Recent research has demonstrated that bacterial community composition experiences changes in response to the addition of DOM (Landa et al., 2013; Sarmento et al., 2013). Studies on the interaction between zooplankton metabolism and bacterial communities are, however, too scarce. Recent reports demonstrate that the addition of excretory products released by zooplankton (krill) stimulates bacterial growth and production in the Southern Ocean (Arístegui et al., 2014). Specific studies carried out by us in a eutrophic coastal zone off southern/central Chile indicate that the nitrogen excreted by copepods generate a specific response from nitrifying communities and the active marine bacterioplankton community (Valdés et al., 2017a, b). Despite the advances over the last decades, studies of the impact of copepod nitrogen and phosphorus excretion on microbial communities from oligotrophic and ultra-oligotrophic areas can provide valuable information about the recycling of these nutrients in larger areas of the ocean.

Herein, we studied the role of organic and inorganic dissolved compounds released by copepods, and its potential effect on their recycling and structuring of the bacterioplankton community during late austral summer in distinct biogeochemical regions of the WTSP. 


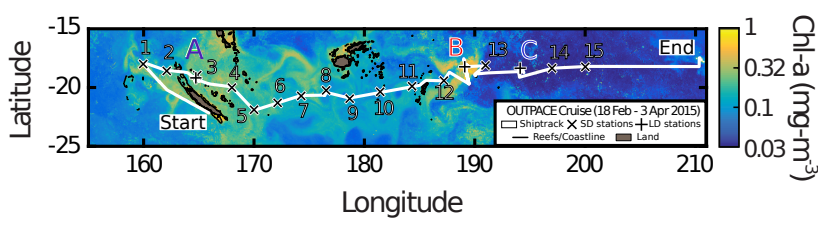

Figure 1. Quasi-Lagrangian surface chlorophyll- $a$ concentration $\left(\mathrm{mg} \mathrm{m}^{-3}\right)$ during the OUTPACE cruise. The satellite data are weighted in time by each pixel's distance from the ship's position for the entire cruise. The white line shows the vessel route (data from the hull-mounted ADCP positioning system). Coral reefs and coastlines are shown in black, land in grey, and areas of no data are left white. The positions of the short- (long-)duration stations are shown by cross (plus) symbols. Experiments were performed at each long-duration station (image courtesy of Alain de Verneil, 2 June 2017).

\section{Material and methods}

\subsection{Study area and sampling strategy}

Sampling was conducted in WTSP during austral summer 2015 (18 February-3 April), on board the RV $L$ 'Atalante. The transect began west of New Caledonia $\left(18^{\circ} \mathrm{S}-159.9^{\circ} \mathrm{E}\right)$ and ended near Tahiti $\left(17.56^{\circ} \mathrm{S}-\right.$ $149.05^{\circ} \mathrm{W}$; Fig. 1). Along this transect, two types of stations were sampled: 15 short-duration stations (SD; $8 \mathrm{~h}$ ) dedicated to large-scale description and three long-duration stations for the Lagrangian studies (LD; approximately 8 days). Experiments were conducted at three long-duration stations: LD A (27 February; $\left.-19.2^{\circ} \mathrm{S}-164.7^{\circ} \mathrm{E}\right)$, LD B (17 March; $\left.-18.2^{\circ} \mathrm{S}-189.1^{\circ} \mathrm{W}\right)$ and $\mathrm{LD} \mathrm{C}\left(24 \mathrm{March} ;-18.4^{\circ} \mathrm{S}-\right.$ $\left.194^{\circ} \mathrm{W}\right)$. These stations were chosen along a regional gradient of oligotrophy and are located in two geographic regions: LD A and LD B in the Melanesian Archipelago (MA) and LD C in the subtropical gyre (SG). These stations were chosen based on the sea surface chlorophyll- $a$ concentration, which was maximum in LD A and LD B, and minimum at the LD C station. More details about the sampling strategy and general biogeochemical and hydrographic characteristics are described in Moutin et al. (2017, 2018). At each sampling station seawater samples were obtained using Niskin bottles (12 L) arranged on a CTD rosette from the deep chlorophyll maximum (DCM). Seawater was collected for chemical and biological initial characterization, including ammonium $\left(\mathrm{NH}_{4}^{+}\right)$, nitrate $\left(\mathrm{NO}_{3}^{-}\right)$, nitrite $\left(\mathrm{NO}_{2}^{-}\right)$, phosphate $\left(\mathrm{PO}_{4}^{3}-\right)$, chlorophyll- $a$, DNA and RNA. The DCM depths correspond to 80, 34 and $140 \mathrm{~m}$ in LD A, LD B and LD C. Details of chlorophyll- $a$ methods are available in Dupouy et al. (2018).

\subsection{Mesozooplankton sampling}

Samples were collected by vertical hauls of a bongo net (70 $\mathrm{cm}$ mouth diameter) of $120 \mu \mathrm{m}$ mesh size, equipped with

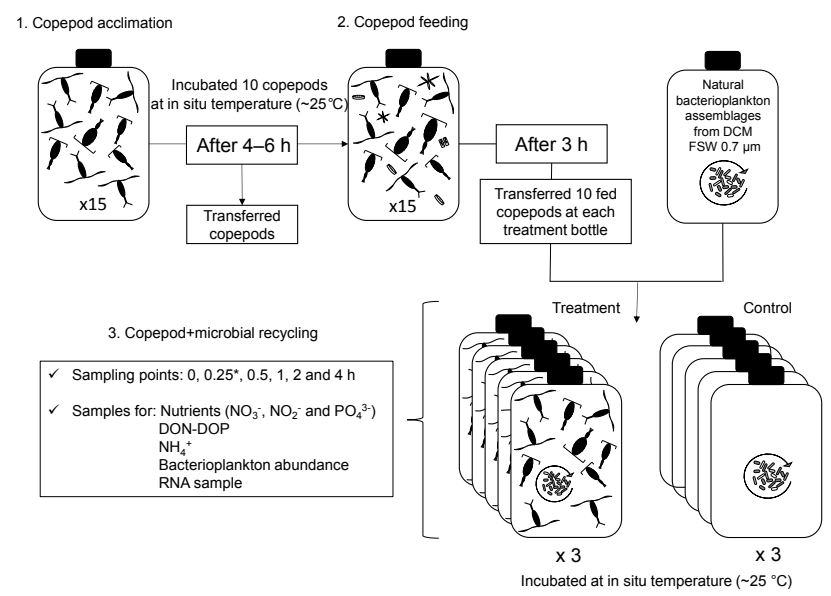

Figure 2. Experimental design. The design consisted of three phases done sequentially. Each bottle with copepods was acclimated for at least $6 \mathrm{~h}$ (phase 1), followed by feeding (phase 2) with the deep chlorophyll- $a$ maximum (DCM) water for $4 \mathrm{~h}$. Copepod and microbial recycling (phase 3 ) was studied by adding natural bacterial assemblages from DCM-filtered seawater (DCM FSW) to the 15 bottles with fed copepod, and maintaining bottles with natural bacterial assemblages and without copepods (controls). Three bottles with copepods and three control bottles were sacrificed at each of the five sampling times. An additional time $\left(0.25 \mathrm{~h}^{*}\right)$ was added for ammonium determination in LD B and LD C.

a nonfiltering cod end with which to obtain undamaged individuals. Mesozooplankton samples were collected at the three LD stations in the upper $100 \mathrm{~m}$ depth at a speed of $1 \mathrm{~m} \mathrm{~s}^{-1}$ under nighttime conditions. Live samples were immediately transferred to coolers until they were sorted in the on-board laboratory.

\subsection{Preparation of the microcosm and experimental setup}

The experimental design had three steps: (1) copepod acclimation, (2) feeding and (3) copepod and microbial recycling (Fig. 2). Seawater for incubations (30 L) was collected into clean $(10 \% \mathrm{HCl}$ rinsed) polycarbonate carboys from the DCM. For acclimation (1) and copepod and microbial recycling (3) steps, seawater (22.5 L) was immediately filtered through a $0.7 \mu \mathrm{m}$ filter (GF/F; Whatman) using a peristaltic pump. The remaining $7.5 \mathrm{~L}$ was used in the feeding phase. Seawater for the different steps was maintained in a temperature-controlled room (in situ temperature $\sim 25^{\circ} \mathrm{C}$ ) until the beginning of the experiment.

Undamaged individuals were sorted from the live samples and identified using a stereomicroscope at low light. Copepod samples in the three experiments consisted of a mix of the most representative copepods (adults) in the sample (Table S1 in the Supplement; More details about zooplankton composition and abundance are available in Carlotti et al., 2018). In the acclimation phase (1), 15 groups of 10 cope- 
pods were incubated in $500 \mathrm{~mL}$ Nalgene bottles, maintained for 4-6h in seawater previously filtered (GF/F Whatman) in darkness and at a controlled temperature (in situ). In the feeding step (2) copepods were removed from the bottles using a sieve $(20 \mu \mathrm{m})$ and maintained in new $500 \mathrm{~mL}$ polycarbonate bottles (Nalgene) with $<150 \mu \mathrm{m}$ filtered seawater (polycarbonate membrane) for feeding. This step lasted $4 \mathrm{~h}$ and, as the acclimatization phase, took place under controlled temperature $\left(25^{\circ} \mathrm{C}\right)$. Thereafter, each copepod group (15 groups) was placed in a new set of $500 \mathrm{~mL}$ polycarbonate bottles (Nalgene) filled with the previously filtered seawater $(0.7 \mu \mathrm{m}$; Millipore) for the copepod and microbial recycling phase. Also, 15 other bottles without copepods were incubated as the control. In total, 30 bottles were used in this step at $\mathrm{LD} \mathrm{A}$, whereas additional bottles were included at LD B and LD C, 6 bottles were added at LD B and LD C, 3 with copepods and 3 without copepods as a control. The seawater was filtered to avoid the presence of phytoplankton and small protists, to minimize the grazing effect and to ensure the presence of natural microbial assemblages. At the end of each step copepods were observed and checked by direct observation to ensure swimming behavior in the bottles. The percentage of mortality at the end of each experiment at each bottle was less than $20 \%$.

During the copepod and microbial response phase, at time intervals of $0 \mathrm{~h}(\mathrm{~T} 0), 0.5 \mathrm{~h}(\mathrm{~T} 1: \mathrm{T} 0+0.5 \mathrm{~h}), 1 \mathrm{~h}(\mathrm{~T} 2: \mathrm{T} 0+1 \mathrm{~h})$, $2 \mathrm{~h}(\mathrm{~T} 3: \mathrm{T} 0+2 \mathrm{~h})$ and $4 \mathrm{~h}(\mathrm{~T} 4: \mathrm{T} 0+4 \mathrm{~h})$, samples were collected for $\mathrm{NH}_{4}^{+}, \mathrm{NO}_{3}^{-}, \mathrm{NO}_{2}^{-}, \mathrm{PO}_{4}^{3}-$, DON, dissolved organic phosphorus (DOP), bacterioplankton abundance and RNA. The samples for the initial time (T0) were taken once all the bottles were incubated. An additional sampling, corresponding to an incubation time of $15 \mathrm{~min}$ ( $\mathrm{T}^{\prime}$ ': $\mathrm{T} 0+0.25 \mathrm{~h}$ ), was added just to have more measurements of $\mathrm{NH}_{4}^{+}$in the experiments of stations LD B and LD C. Six bottles were discarded each time, three for treatment with copepods and three for the control (without copepods). The three bottles sacrificed at each time represented triplicates for treatment and control.

At the end of each observation time, copepod samples were preserved immediately with formalin buffered by sodium borate ( $5 \%$ final concentration) for further zooplankton identification analysis (Table S1).

\subsection{Dissolved inorganic and organic nutrients measurements}

Nutrient samples $\left(\mathrm{NO}_{3}^{-}, \mathrm{NO}_{2}^{-}\right.$and $\left.\mathrm{PO}_{4}^{3}-\right)$ were taken in duplicate in $20 \mathrm{~mL}$ HDPE bottles, filtered through $0.7 \mu \mathrm{m}$ filters (GF/F; Whatman) and poisoned with $\mathrm{HgCl}_{2}$ to a final concentration of $20 \mu \mathrm{g} \mathrm{L}^{-1}$. Samples were stored at $-20^{\circ} \mathrm{C}$ and analyzed on board and determined by standard colorimetric techniques (Aminot and Kérouel, 2007) using a SEAL Analytical AA3 HR system (SEAL Analytical, Serblabo Technologies, Entraigues Sur La Sorgue, France). Samples for $\mathrm{NH}_{4}^{+}$determination $(40 \mathrm{~mL})$ were taken in duplicate and analyzed on board using a Jasco FP-2020 fluorometer, according to Holmes et al. (1999). Samples for DON and DOP (30 mL) were filtered through precombusted $\left(450^{\circ} \mathrm{C}, 6 \mathrm{~h}\right) \mathrm{GF} / \mathrm{F}$ filters (Whatman). Samples were collected in Teflon bottles and analyzed immediately on board using the wet oxidation method (Pujo-Pay and Raimbault, 1994). DON and DOP concentrations were determined by sample oxidation $\left(30 \mathrm{~min}, 120^{\circ} \mathrm{C}\right)$ and corrected for $\mathrm{NO}_{3}^{-}, \mathrm{NO}_{2}^{-}$and $\mathrm{PO}_{4}^{3}-$ concentrations.

\subsection{Bacterioplankton abundance, and DNA and RNA extraction}

Bacterioplankton abundance was determined by flow cytometry. From each bottle $1350 \mu \mathrm{L}$ samples were fixed in sterile cryovials with glutaraldehyde (at $0.1 \%$ final concentration). The samples were stored at $-80^{\circ} \mathrm{C}$ until laboratory analysis. Samples were analyzed by flow cytometry (FACScan, Becton Dickinson) at the Observatorire Océanologique de Banyuls sur Mer, France. The abundance of nonfluorescent picoplankton was estimated from samples previously stained with SYBR green I (Molecular probes) according to Marie et al. (1997). DNA samples for the initial characterization of bacterial communities were collected at DCM depth of each sampling site. Samples (9-10L) were filtered through cellulose ester filters ( $0.22 \mu \mathrm{m}$; Millipore) using a peristaltic pump and stored with RNA later reagent (Ambion) at $-20^{\circ} \mathrm{C}$ until extraction procedures.

DNA was isolated using a PowerSoil DNA Isolation Kit (MoBio Laboratories) in accordance with the manufacturer's specifications following Levipan et al. (2014). DNA was quantified by spectrophotometry (NanoDrop ND-1000 spectrophotometer). RNA samples were collected for initial characterization of the active bacterial community at DCM at each LD station and during each experiment to study the composition of the active bacterial community. Seawater $(100 \mathrm{~mL})$ was filtered using a sterilized syringe and $25 \mathrm{~mm}$ swinnex through $0.22 \mu \mathrm{m}$ hydrophilic PVDF filters (Millipore) and the filters were preserved with RNAlater solution (Ambion) and stored at $-80^{\circ} \mathrm{C}$ until RNA extraction procedures were carried out.

RNA samples were extracted using a mirVana kit (AM1560; Ambion) in accordance with the manufacturer's instructions, including a mechanical disruption step and homogenization using $200 \mu \mathrm{m}$ diameter zirconium beads (Low Binding Zirconium Beads, OPS Diagnostic). They were homogenized twice at $\sim 3000 \mathrm{rpm}$ for $30 \mathrm{~s}$ by using MiniBeadbeater-8TM (Biospec Products). In order to remove DNA traces, RNA was treated with a TURBO DNA-free Kit (Ambion). Finally, concentration and quality (A260/A280 ratio) of RNA extracts as well as DNA extracts were determined by spectrophotometry (NanoDrop ND-1000 spectrophotometer). 


\subsection{Analysis of the bacterial community structure}

The bacterial community structure was analyzed using the Illumina MiSeq sequencing method from 16S rRNA (samples from incubation), using cDNA as template, and $16 \mathrm{~S}$ rDNA in situ, following Campbell and Kirchman (2013). cDNA was generated using random primers provided by the ImProm-IITM Reverse Transcription System (Promega). Bacterial 16S rRNA gene libraries from the V1-V3 region (27F-519R) were generated at the Molecular Research LP (www.mrdnalab.com, last acces: 31 March 2017, Shallowater, TX, USA).

The 16S rRNA and rDNA gene sequences were processed using Mothur software v1.35.1 (Schloss et al., 2009). Sequencing data sets were curated by quality filtration to minimize the effects of random sequencing errors by eliminating sequence readings $<200 \mathrm{bp}$ and trimming of sequences that contained more than one undetermined nucleotide $(\mathrm{N})$ and sequences with a maximum homopolymer length of eight nucleotides. Chimeric sequences were identified using the Chimera UCHIME algorithm (Edgar et al., 2011) and removed to retain high-quality readings.

The 16S rRNA and rDNA gene sequences retrieved were taxonomically classified using the automatic software pipeline SILVAngs available from https://www.arb-silva.de/ (last acces: 31 March 2017) (Quast et al., 2013). At the LD A station, a total of 178097 sequences were analyzed, ranging between 10831 and 19703 sequences for each library (Fig. S1). At the LD B station 219019 sequences were analyzed from 15260 to 20966 for each library, and in LD C 230805 sequences were analyzed, ranging between 13699 and 22104 sequences for each library. At each of the three LD stations, the highest number of sequences correspond to DNA in situ. Libraries were deposited in the European Nucleotide Archive (ENA) under study accession PRJEB21648 with the following run access numbers: ERS1810581-ERS1810616.

The composition was identified at phyla, class and order taxonomic levels as abundant $(>0.5 \%)$ and others $(<$ $0.5 \%$ ) in total sequences retrieved from each library. The chao1, Shannon and evenness indices were calculated using Past3 software. Since the number of sequences per sample was variable, we previously normalized the different library sizes using a subsampling routine in Mothur software version 1.36 (Schloss et al., 2009) to reflect the lowest number of sequences encountered (LD A: 10 831; LD B: 15260 and LD C: 13 699).

\subsection{Statistical analysis}

Statistical analysis of treatments effects on chemical and biological parameters were performed using a two-way analysis of variance (ANOVA) after checking normality assumptions (Kolmogorov-Smirnov test) and homoscedasticity (Levene's test). Pairwise multiple comparisons were performed using
Table 1. Deep chlorophyll- $a$ maximum (DCM) depth, temperature, chlorophyll- $a$, ammonium $\left(\mathrm{NH}_{4}^{+}\right)$, nitrate $\left(\mathrm{NO}_{3}^{-}\right)$, nitrite $\left(\mathrm{NO}_{2}^{-}\right)$, phosphate $\left(\mathrm{PO}_{4}^{3}-\right)$ concentration, DIN : DIP ratio, DON and DOP concentrations in the DCM at each sampling site. DON and DOP concentrations were extracted from Moutin et al. (2018).

\begin{tabular}{|c|c|c|c|}
\hline & LD A & LD B & LD C \\
\hline $\mathrm{DCM}(\mathrm{m})$ & 80 & 34 & 140 \\
\hline Temperature $\left({ }^{\circ} \mathrm{C}\right)$ & 25.6 & 27.5 & 22.9 \\
\hline Chlorophyll- $a\left(\mu \mathrm{g} \mathrm{L}^{-1}\right)$ & 0.29 & 0.79 & 0.57 \\
\hline $\mathrm{NH}_{4}^{+}\left[\mu \mathrm{mol} \mathrm{L}{ }^{-1}\right]$ & $0.03 \pm 0.00$ & $0.01 \pm 0.00$ & $0.02 \pm 0.00$ \\
\hline $\mathrm{NO}_{2}^{-}\left[\mu \mathrm{mol} \mathrm{L}^{-1}\right]$ & $0.06 \pm 0.00$ & $0.02 \pm 0.02$ & $0.05 \pm 0.00$ \\
\hline $\mathrm{NO}_{3}^{-}[\mu \mathrm{mol} \mathrm{L}-1]$ & $1.53 \pm 0.01$ & $0.05 \pm 0.02$ & $0.25 \pm 0.01$ \\
\hline $\mathrm{PO}_{4}^{3}-\left[\mu \mathrm{mol} \mathrm{L}^{-1}\right]$ & $0.16 \pm 0.01$ & $0.03 \pm 0.03$ & $0.24 \pm 0.01$ \\
\hline DIN : DIP & $9.97 \pm 0.70$ & $4.52 \pm 4.07$ & $1.21 \pm 0.11$ \\
\hline $\mathrm{DON}\left[\mu \mathrm{mol} \mathrm{L}^{-1}\right]$ & 4.78 & 5.88 & 4.49 \\
\hline $\mathrm{DOP}[\mu \mathrm{mol} \mathrm{L}-1]$ & 0.12 & 0.18 & 0.11 \\
\hline
\end{tabular}

a Tukey test as a posteriori analysis. Statistical significance was set to $p=0.05$ and analysis was computed using $\mathrm{R}$ software. The time point sampled at $15 \mathrm{~min}$ was not considered for this analysis, because there were too few data.

Changes in bacterial community structure were compared using ordination Bray-Curtis similarities and used to build dendrograms by the unweighted pair group method with arithmetic averages (UPMG). For multivariate statistical analysis, the software package PRIMER v.6 and the add-on PERMANOVA+ were used. The permutational multivariate analysis of variance (PERMANOVA) with a fixed factor was applied to investigate the differences in bacterial community composition for treatments and control in both experiments. Principal coordinate analysis ( $\mathrm{PCO}$ ) was performed to visualize patterns of the bacterial community in response to the different treatments.

\section{Results}

\subsection{Biogeochemical in situ conditions}

Inorganic nutrients concentrations, obtained at the DCM depth, varied substantially between the sampling sites (Table 1). Lower concentrations close to the limit of detection of the methods of $\mathrm{NH}_{4}^{+}, \mathrm{NO}_{3}^{-}, \mathrm{NO}_{2}^{-}$and $\mathrm{PO}_{4}^{3}$ - were observed in LD B, compared to LD A and LD C. The highest concentrations were observed in LD A, particularly for $\mathrm{NO}_{3}^{-}\left(1.53 \mu \mathrm{mol} \mathrm{L}{ }^{-1}\right)$. The resulting DIN : DIP ratio showed greater values in $\mathrm{LD} A(9.97 \pm 0.70)$ than in LD B and LD C, and the lowest DIN : DIP ratio $(1.21 \pm 0.11)$ was estimated for LD C seawater.

\subsection{Changes in inorganic nutrients, DON and DOP during the incubations}

Inorganic nitrogen and phosphorus concentrations changed substantially over the course of the experiments at the three 


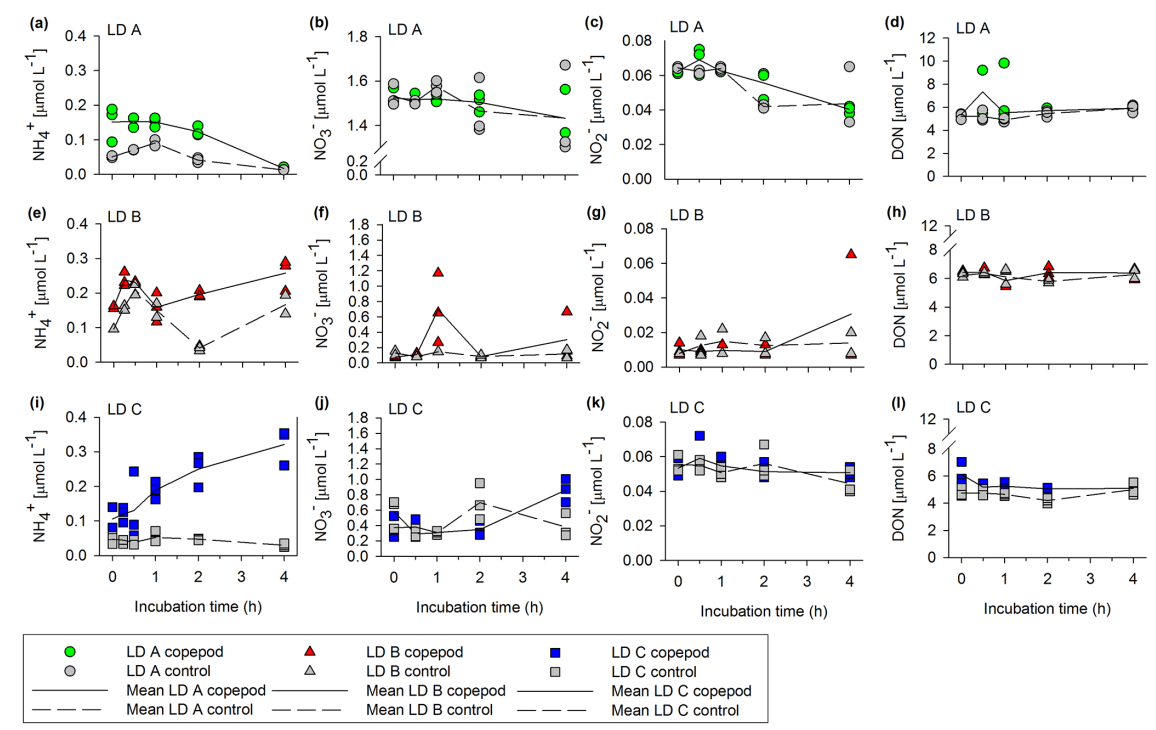

Figure 3. (a, e, i) Ammonium $\left(\mathrm{NH}_{4}^{+}\right),(\mathbf{b}, \mathbf{f}, \mathbf{j})$ nitrate $\left(\mathrm{NO}_{3}^{-}\right),(\mathbf{c}, \mathbf{g}, \mathbf{k})$ nitrite $\left(\mathrm{NO}_{2}^{-}\right)$and $(\mathbf{d}, \mathbf{h}, \mathbf{l})$ dissolved organic nitrogen $(\mathrm{DON})$ variability over the incubation period for treatments with copepods and control (without copepods) in each LD experiment.
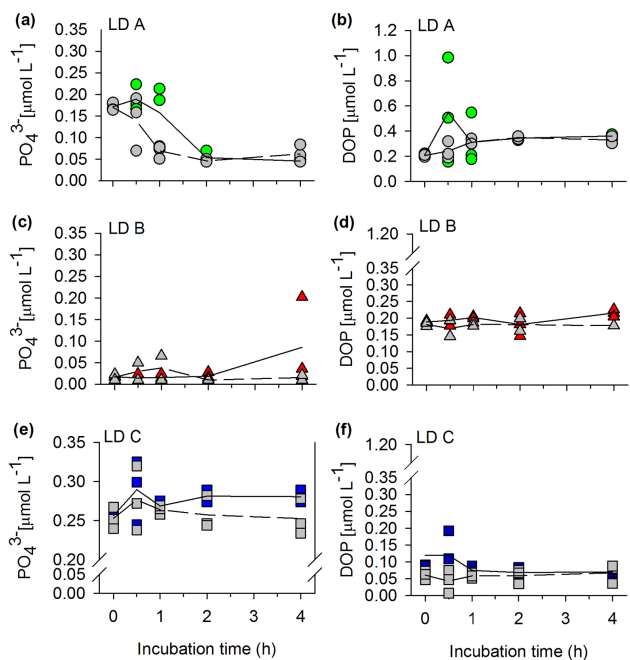

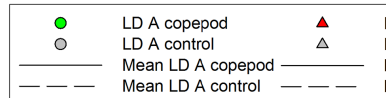

\begin{tabular}{|c|c|c|}
\hline & $\begin{array}{l}\square \\
\square\end{array}$ & \\
\hline $\begin{array}{l}\text { Mean LD B copepod } \\
\text { Mean LD B control }\end{array}$ & & Mean LD C copepod \\
\hline
\end{tabular}

Figure 4. (a, c, e) Phosphate $\left(\mathrm{PO}_{4}^{3}-\right)$ and $(\mathbf{b}, \mathbf{d}, \mathbf{f})$ dissolved organic phosphorus (DOP) variability over the incubation period for treatments with copepods and control (without copepods) in each LD experiment.

LD stations (Figs. 3 and 4). Ammonium concentrations (Fig. 3a, e, i) increased significantly (4- and 7-fold) in the presence of copepods in all experiments (ANOVA, LD A: $\mathrm{F}_{1,20}: 93.2, p<0.001 ; \mathrm{LD} \mathrm{B}: \mathrm{F}_{1,18}: 61.7, p<0.001 ; \mathrm{LD}$ $\left.\mathrm{C}: \mathrm{F}_{1,20}: 108.9, p<0.001\right)$. The largest and most significant difference in ammonium concentration with respect to the controls was associated with T0 in LD A, T3 in LD B and
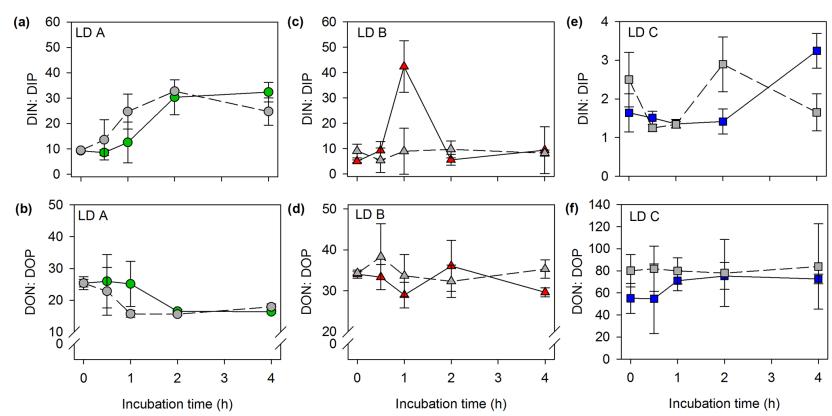

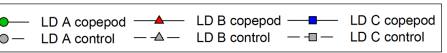

Figure 5. (a, c, e) $\mathrm{N}: \mathrm{P}$ ratios of the inorganic (DIN : DIP) and (b, d, f) organic (DON : DOP) nutrients over the incubation period for treatments with copepods and control (without copepods) in each LD experiment.

T4 in LD C (ANOVA and Tukey's test $p<0.001$; Table S2). Nitrate showed significant differences between the treatment with copepods and controls in LD B and LD C; characterized by notable accumulation in the treatment with copepods (Fig. 3f, j) at T1 in LD B (ANOVA and Tukey's test $p=0.02$; Table S2), and at T4 in LD C experiments (ANOVA and Tukey's test $p=0.009$; Table S2). Nitrite (Fig. 3c, g, k) was slightly variable through time in the experiments and no significant difference was detected between copepods and the controls (ANOVA, LD A: $\mathrm{F}_{1,16}: 0.50, p=0.49$; LD B: $\mathrm{F}_{1,18}$ : $0.13, p=0.7$; LD C: $\mathrm{F}_{1,20}: 0.44, p=0.51$ ). DON (Fig. 3d, $h, 1)$ showed significant differences between the treatment and control in LD A and LD C (ANOVA, LD A: $F_{1,20}: 8.99$, $p=0.007$; LD C: $\left.\mathrm{F}_{1,20}: 29.0, p<0.0001\right)$, and these differences were associated with the increment in concentration at 


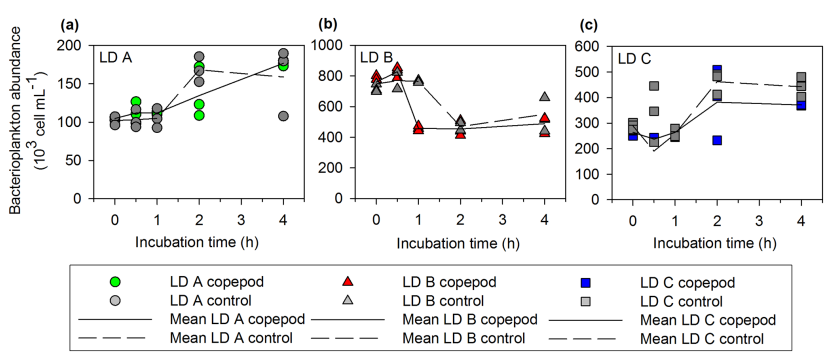

Figure 6. Bacterioplankton abundance over the incubation period for treatments with copepods and control (without copepods) in each LD experiment. (a) LD A, (b) LD B and (c) LD C.

T1 in LD A and T0 in LD C in the treatment with copepods. At LD B nonsignificant differences were detected between treatments and controls over time (ANOVA, $p>0.05$ ).

Phosphate in LD A showed a higher concentration during the first hour of incubation, followed by a sharp decrease (from 0.17 to 0.05 , approximately; Fig. $4 a$ ) in the treatment with copepods as well as the control. Despite significant differences in time (ANOVA, $\mathrm{F}_{1,20}: 17.7, p<$ 0.0001 ), treatment versus control differences were not significant (ANOVA, $\mathrm{F}_{1,20}: 4.5, p=0.06$ ). Also, no significant differences in phosphate distribution through time and between treatments were found in the LD B and LD C experiments (Fig. 4c, e; ANOVA, LD B: $\mathrm{F}_{1,18}: 0.13, p=0.7$; LD C: $\mathrm{F}_{1,20}: 0.44, p=0.51$ ). DOP concentrations (Fig. $4 \mathrm{~b}, \mathrm{~d}, \mathrm{f}$ ) did not vary significantly through time in the three experiments (ANOVA, LD A: $\mathrm{F}_{1,20}: 0.3, p=0.87$; LD B: $\mathrm{F}_{1,20}$ : $0.5, p=0.43$; LD C: $\mathrm{F}_{1,20}: 0.70, p=0.60$ ), but significant differences were only observed between the treatment with copepods and control in LD B and LD C (ANOVA, LD A: $\mathrm{F}_{1,20}: 0.43, p=0.52$; LD B: $\mathrm{F}_{1,20}: 8.92, p=0.008$; LD C: $\left.\mathrm{F}_{1,20}: 7.94, p=0.01\right)$.

During the experiments, the resulting DIN:DIP and DON : DOP ratios are shown in Fig. 5. In the LD A experiment the DIN : DIP ratios (Fig. 5a) were lower than Redfield ratios during the first hour of incubation followed by a ratio increment from 12.5 to 32.4 at the end of incubation, only in the treatment with copepods, whereas a decrease in the DIN : DIP ratio was observed at the end of the incubation in the controls. In the same experiments in LD A, the DON : DOP ratio decreased from 25 to 16.4 at the end of the experiment (Fig. 5b). In the LD B experiment (Fig. 5c), a lower DIN : DIP than Redfield ratio was found throughout the experiment, suggesting a nitrogen deficiency relative to phosphorus, except at $1 \mathrm{~h}$ of incubation when a higher DIN : DIP ratio was observed (2.6 times higher than Redfield) in the treatment with copepods, linked to a nitrate increment (see Fig. 3f). The DON : DOP ratios were higher than the Redfield ratio in the treatment with copepods and the control (Fig. 5d). In LD C the DON : DOP ratio (Fig. 5f) indicated a substantial accumulation of nitrogen with respect to phosphorus from the first hour of the incubation in the treat-
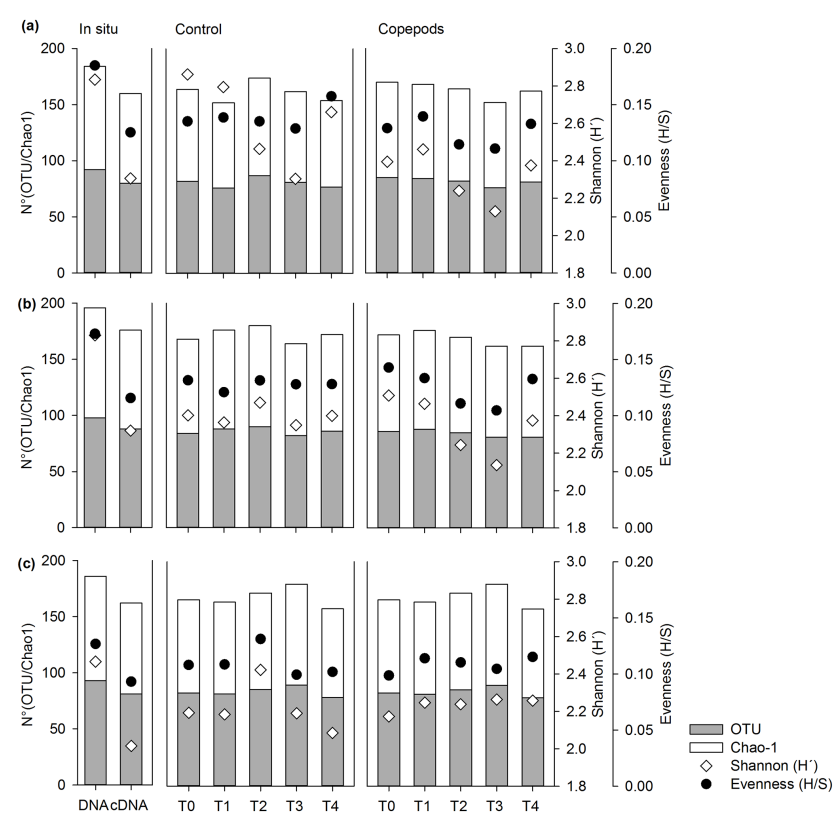

Figure 7. Richness, chao1, diversity (Shannon) and evenness from the total and active in situ bacterial community and over the incubation period for the active bacterial community at each LD experiment: (a) LD A, (b) LD B and (c) LD C.

ment with copepods, showing an important deviation from the Redfield ratio (> $16: 1$ ).

\subsection{Changes in bacterioplankton abundance during the experiment evolution}

Changes in bacterioplankton abundance are shown in the Fig. 6. Initial experimental conditions showed that bacterioplankton were more abundant in LD B, followed by LD C and LD A experiments. In the LD A experiment (Fig. 6a) bacterioplankton presented an increase over time towards the end of the incubation, from $100 \times 10^{3}$ to $200 \times 10^{3}$ cell $\mathrm{mL}^{-1}$, showing significant statistical differences between the sampling times (ANOVA, F1, 20: 13.5, $p<0.001$ ) but not between treatments (ANOVA, $\mathrm{F}_{1,20}: 0.004, p=0.95$ ). In contrast, in the LD B experiment (Fig. 6b), a decrease in bacterioplankton abundance (around $300 \times 10^{3}$ cell $\mathrm{mL}^{-1}$ ) was observed between 0.5 and $1 \mathrm{~h}$ and between 1 and $2 \mathrm{~h}$ of incubation in copepod and control treatments, respectively, giving significant differences between both sampling times $\left(\mathrm{F}_{1,16}: 33.8, p<0.000\right)$ and treatments (copepods and control; ANOVA, $\mathrm{F}_{1,16}: 7.69, p=0.014$ ). In LD C (Fig. 6c), a strong difference $\left(>200 \times 10^{3}\right.$ cell $\left.\mathrm{mL}^{-1}\right)$ was observed between sampling times (ANOVA, $\mathrm{F}_{1,20}: 9.93, p<0.000$ ) and between treatments and control (ANOVA, $\mathrm{F}_{1,20}: 6.22$, $p=0.02$ ). 


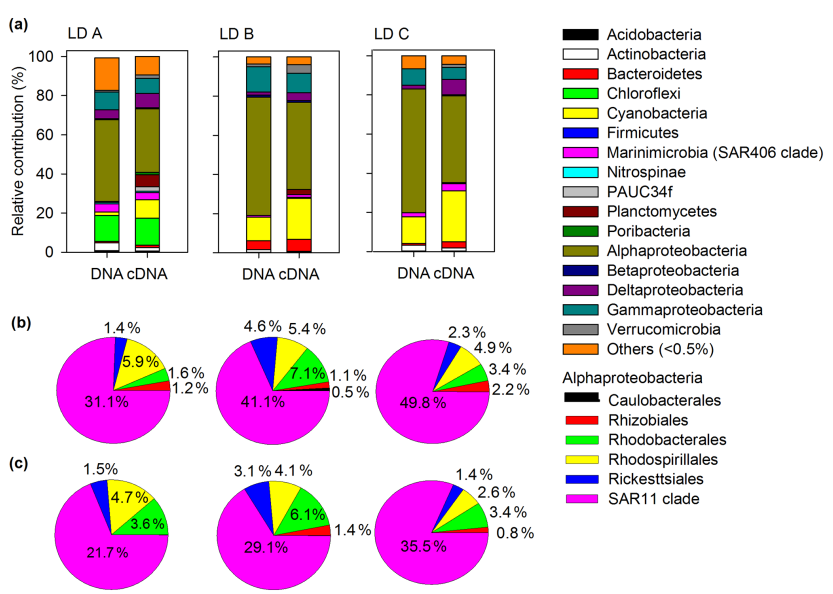

Figure 8. (a) Relative abundance of major bacteria phyla and Proteobacteria class at each LD station, with the Alphaproteobacteria order at initial in situ conditions for the three sampling sites: (b) total Alphaproteobacteria (DNA) and (c) active Alphaproteobacteria community (cDNA).

\subsection{Active bacterial composition and their response during the incubations}

The alpha diversity derived from normalized 16S rDNA and rRNA libraries is shown in the Fig. 7. The bacterial taxonomic richness determined (OTU number) and expected on the chaol index was higher in DNA in situ compared to the cDNA in situ and the samples related to the experiment. In accordance, the Shannon diversity index showed that the bacterial community obtained in situ from $16 \mathrm{~S}$ rDNA reached higher values compared with the incubated community. The alpha diversity showed slight differences between the treatments with copepods in the three experiments. These differences were characterized by higher values at the beginning of the incubation at the LD A and LD B stations (T1 and T2, respectively; Fig. 7a and c) and by higher diversity values at the end of the experiments (T4) in the treatment with copepods at the LD C station (Fig. 7b).

The total in situ bacterial community composition (Fig. 8a) was characterized by a higher contribution of Alphaproteobacteria, mainly by SAR 11 , dominating slightly more in $\mathrm{LD} \mathrm{C}$, followed by $\mathrm{LD} \mathrm{B}$ and $\mathrm{LD} \mathrm{A}$, respectively and reaching $49.8 \%, 41.1 \%$ and $31.1 \%$ of libraries derived from DNA (Fig. 8b). Cyanobacteria were also present in our libraries with a higher contribution in LD C than in LD A and LD B. In addition, a high number of abundant phyla were observed in LD A compared to the other stations. Additionally, the active in situ bacterial composition (Fig. 8c) 16S rRNA was consistent with 16S rDNA, with a predominance of Alphaproteobacteria and SAR11 class followed by the same trend (Fig. $8 \mathrm{~b}$ and c), with a higher contribution in LD C followed by LD B and LD A stations.
In general, clustering analyses showed that the active bacterial community composition varied significantly during the incubation compared to the in situ community in the three experiments (Fig. 9). During LD A incubation, the bacteria community composition was characterized by an increase in Gammaproteobacteria from $39 \%$ to $68 \%$ in T0 and T4 in the copepod treatments (Fig. 9a). Also, a decrease in Cyanobacteria, Chloroflexi and other low frequent taxa was found. During the experiment at LD B, smaller differences in taxa contribution were observed over the incubation period. Gammaproteobacteria increased their contribution through the incubation from $28 \%$ at T0 to $32 \%$ at T4 (Fig. 9b). In contrast to the other experiments, the incubation at LD C (Fig. 9c) presented a decrease in Gammaproteobacteria contribution and an increase in Alphaproteobacteria. The cluster analysis (Fig. 9) associated with contribution changes to bacterial orders during the experiments indicate that the variability was mainly associated with the incubation time, T0, $\mathrm{T} 1$ and $\mathrm{T} 2$ versus $\mathrm{T} 3$ and $\mathrm{T} 4$, in $\mathrm{LD} \mathrm{A}$ and $\mathrm{LD} \mathrm{B}$ experiments. However, in the LD C experiment the bacterial orders were mainly grouped by treatments without the effect of incubation time (with and without copepods; Fig. 9c).

In addition, the greatest dissimilarities, based on SIMPER analysis (Fig. 10; Table S3), between copepod treatments and the control in LD A (Fig. 10a) were mainly due to an increase in Alteromonadales and Oceanospirillales in the treatment with copepods, whereas SAR11 and Rhodobacterales increase their relative abundance in controls. In the LD B experiment (Fig. 10b), smaller dissimilarities between treatment and control $(9.5 \%)$ were observed and were mainly due to a successive decrease in Alteromonadales contribution and increase in SAR11 contribution in the treatment with copepods. In contrast, at the LD C station (Fig. 10c), the dissimilarities were mainly due to a larger contribution in $\mathrm{Al}$ teromonadales and were replaced by SAR 11 at the end of the incubation in the treatment with copepods. The specific order contribution for the three experiments are shown in Figs. S2, $\mathrm{S} 3$ and $\mathrm{S} 4$, as abundant $(>0.5 \%)$, semirare $(0.5 \%-0.1 \%)$ and rare $(<0.1 \%$; Pedrós-Alió, 2012).

PCO analysis with order contribution and environmental parameters indicates that in the LD A experiment the initial sampling points (T0, T1 and T2) were associated with inorganic compounds $\left(\mathrm{NH}_{4}^{+}, \mathrm{NO}_{3}^{-}, \mathrm{NO}_{2}^{-}\right.$and $\mathrm{PO}_{4}^{3}-$; Fig. 11a) for the treatment with copepods and the control. Meanwhile, nitrite concentrations were associated with the last time points in LD B (Fig. 11b). In the LD C experiment (Fig. 11c), no visual association was observed between environmental parameters and the order contribution. In addition, the main PERMANOVA test revealed significant differences among all samples regarding the different experiments (pseudo- $\mathrm{F}=12.7, p=0.001$ ). However, differences between treatments with copepods and the control, and between times do not show significant differences (PERMANOVA, pseudo-F $=2.1-1.3, p=0.12-0.25$ ). 
(a)

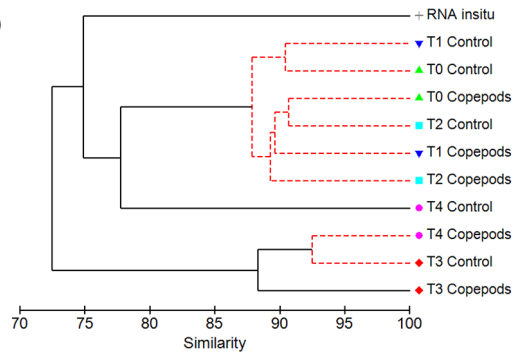

(b)

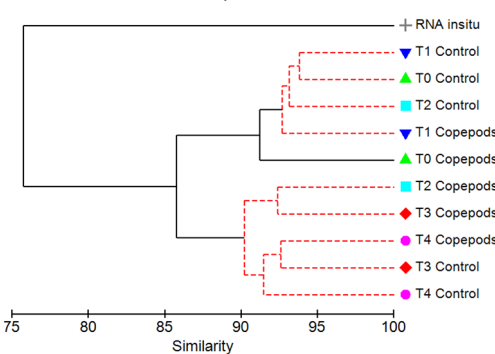

(c)

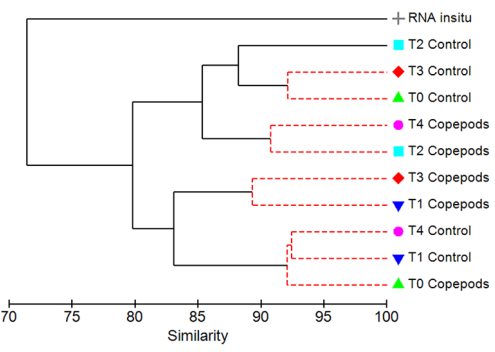

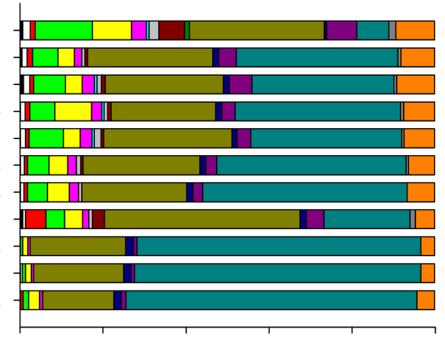
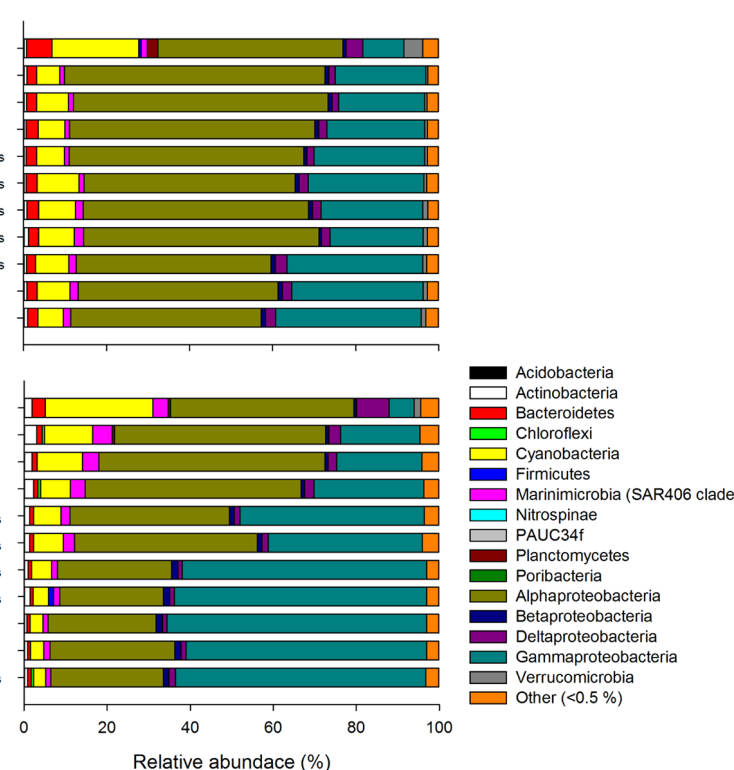

Figure 9. Similarity dendrograms based on the 16S rRNA and relative contribution of the abundant bacteria phyla and Proteobacteria subclasses for the initial in situ community, treatments with copepods and controls (left panel) over the incubation period for the three experiments (a) LD A, (b) LD B and (c) LD C. Clustering is on the basis of a distance matrix computed using the Bray-Curtis index of similarity. The dendrogram was inferred with the unweighted pair-group average algorithm (UPGMA). Bacterial communities in the samples connected with red branch lines are not significantly different (SIMPROF test, $p<0.05$ ).

\section{Discussion}

The two oceanographic regions in which our experiments were performed presented contrasting trophic conditions. The MA region was characterized by a gradient of nutrient conditions, with the highest and the lowest nitrate concentrations in LD A and LD B, respectively. Both stations were characterized by the presence of Trichodesmium spp. bloom, with higher $\mathrm{N}_{2}$ fixation rates (Bonnet et al., 2017; Caffin et al., 2018). In accordance with the satellite data, de Verneil et al. (2018) suggest that the low nutrient concentration found in LD B was the consequence of a 2-month old diazotrophs bloom. In contrast to the MA region, the SG region is characterized by lower nitrate concentrations and higher phosphate concentrations, resulting in lower DIN : DIP ratio. These conditions were reflected in the abundance and composition of zooplankton, and also in the composition of bacterioplankton. In the case of zooplankton, the average abundance in the MA region was 1,212 ind. $\mathrm{m}^{-3}$ ( $\mathrm{sd}=334$ ind. $\mathrm{m}^{-3}$, highest value 2,017 ind. $\mathrm{m}^{-3}$ ), whereas in the SG region the aver- age abundance was 665 ind. $\mathrm{m}^{-3}\left(\mathrm{sd}=213\right.$ ind. $\mathrm{m}^{-3}$, highest value 409 ind. $\mathrm{m}^{-3}$; Carlotti et al., 2018). On the other hand, the bacterioplankton community composition revealed a higher diversity in the MA region compared to SG, with a higher dominance of Alphaproteobacteria in both regions; however, SAR 11 increased their contribution in the ultraoligotrophic area (SG).

\subsection{Biogeochemical changes in response to the dissolved compounds released by copepods}

During our study, we evidenced that copepods exert an influence on biogeochemical composition during the incubations at contrasting trophic conditions including ultra-oligotrophic (SG) versus oligotrophic conditions (MA), showing a significant increase in ammonium and DON accumulation. In addition, copepods influence DON recycling but differentially at the different stations. In the experiment with copepods carried out at the LD A station, higher DON concentrations were observed at initial times (between 0 and $1 \mathrm{~h}$ ). This DON was actively consumed between 1 and $2 \mathrm{~h}$ of incubation. How- 


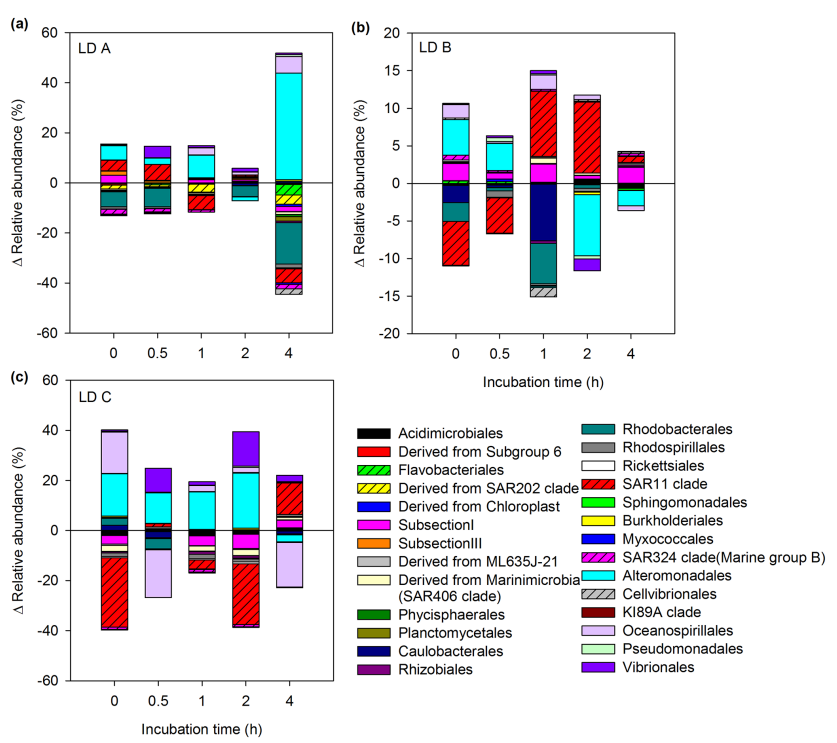

Figure 10. Contribution of active orders over the incubation period based on the SIMPER results. List of the OTUs explaining $50 \%$ of the dissimilarity observed through the experiment between treatment with copepods (top) and control (bottom) for each LD experiment: (a) LD A, (b) LD B and (c) LD C.

ever, this higher DON consumption $\left(3.62 \mu \mathrm{mol} \mathrm{L}^{-1} \mathrm{~h}^{-1}\right.$; Table S4) was not regenerated, since ammonium did not accumulate with time. In addition, at the same time and until the end of the incubation period, an increase in bacterioplankton abundance was observed $\left(22.8 \times 10^{3}\right.$ cell $\left.\mathrm{mL}^{-1}\right)$. Although this increase was nonstatistically significant, it has been reported that zooplankton can release highly labile compounds through their metabolism, and these compounds can be rapidly assimilated by microbial communities, as heterotrophic bacteria in a variety of marine environments (Arístegui et al., 2014; Vargas et al., 2007). On the other hand, the second experiment carried out in the MA region (at LD B) evidenced a potential nitrification associated with copepod excretion. This is because, at the initial time, a decrease in ammonium concentration (between 0.5 and $1 \mathrm{~h}$ of incubation) related to nitrate accumulation (highly variable between the triplicates) was observed in the treatment with copepods but not observed in the control. Nitrifying and heterotrophic communities can rapidly respond to DON and ammonium pulses excreted by copepods in the upwelling area off central Chile, which revealed a tight coupling between excretion and the functional microbial groups involved in ammonia oxidation (Valdés et al., 2017a).

In the SG region (at the LD C station), the experiment with copepods presented the greatest evidence of DON remineralization/ammonification based on the differences in ammonium concentrations between copepod treatments and the control up to $0.3 \mu \mathrm{mol} \mathrm{L}{ }^{-1}$, several times higher than the in situ concentration (Table 1). DON consumption was observed through the first $2 \mathrm{~h}$ of incubation in the treatment with copepods (Fig. 3; Table S4). In addition, as in LD B, nitrate accumulation was observed at the end of incubation in the treatment with copepods compared to the control. Our results suggest the presence of two processes which could occur at the ultra-oligotrophic station in the SG: the release of DON by copepods stimulating ammonium regeneration by bacteria and the increment in nitrate concentration strongly linked to the nitrification process. Thus, DON remineralization could provide an additional substrate for microbial and phytoplankton growth at the LD C station. In this sense, Raimbault and Garcia (2008) demonstrate that in the very low productive area of the South Pacific Gyre, most of the primary production is sustained by active regeneration process, being nitrification active in surface layer, and often balances the biological demand for nitrate. These results support the idea that DON excretion by copepods in oligotrophic and ultraoligotrophic water could play a major role in nitrogen cycling.

On the other hand, DOP showed significantly higher concentrations in the treatment with copepods compared to the control in the three experiments, not over the whole incubation period but over shorter durations. Our results suggest that copepods could potentially contribute a substantial amount of DOP and provide an alternative source of phosphorus for phytoplankton and microbial loop in this study area. The contribution of DOP by copepods could contribute to maintain the longer bloom in this region (MA), providing an additional source of phosphorus for biomass growth. Trichodesmium spp. are capable of hydrolyzing DOP compounds (Mulholland et al., 2002), thus the zooplankton metabolism could potentially supply a significant portion of the cellular phosphorus necessary for their growth.

In this study, the increase in the concentration of the different compounds cannot be attributed only to the excretion process. Firstly, leaching is one of the possible pathways through which zooplankton can release dissolved compounds, along with sloppy feeding and excretion. However, it has been demonstrated that the contribution provided by leaching is insignificant compared to excretion, less than $6 \%$ in the case of the release of DON, whereas ammonium was undetected (Saba et al., 2011; Steinberg et al., 2000). We did not monitor leaching from fecal pellets produced during our experiments, considering leaching from fecal pellets as negligible, and then DON accumulation could account for up to $1.91 \mu \mathrm{mol} \mathrm{L}^{-1} \mathrm{~h}^{-1}$ excretion in the LD A experiment. However, the experimental copepod densities were several orders of magnitude higher than those expected in situ (10 copepods for $0.5 \mathrm{~L}$ volume, i.e., 20000 ind. $\mathrm{m}^{-3}$ ). Consequently, our results might be overestimated, because copepod concentration in our bottles did not reflect the in situ abundance found at each LD station (MA: 1500 ind. $\mathrm{m}^{-3}$ and SG: 500 ind. $\mathrm{m}^{-3}$; Carlotti et al., 2018). However, such concentration was strictly necessary through the experiments to obtain a signal in ammonium concentrations, which were very low in the study area (Table 1). In addition, we cannot 
(a)

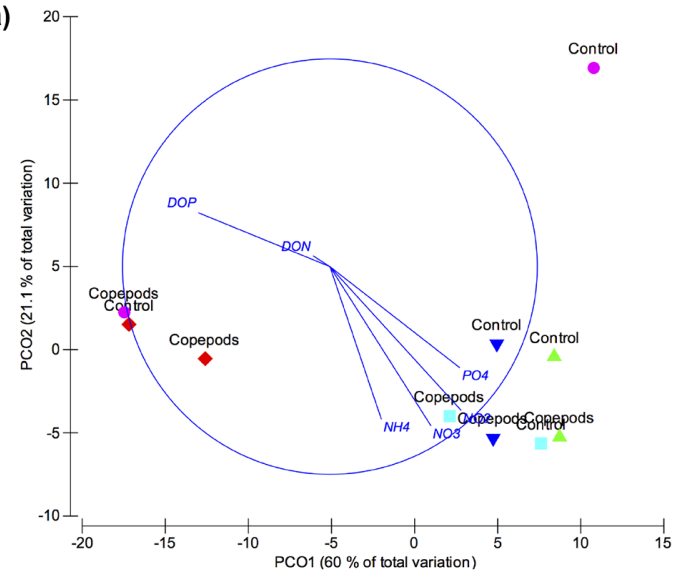

(c)

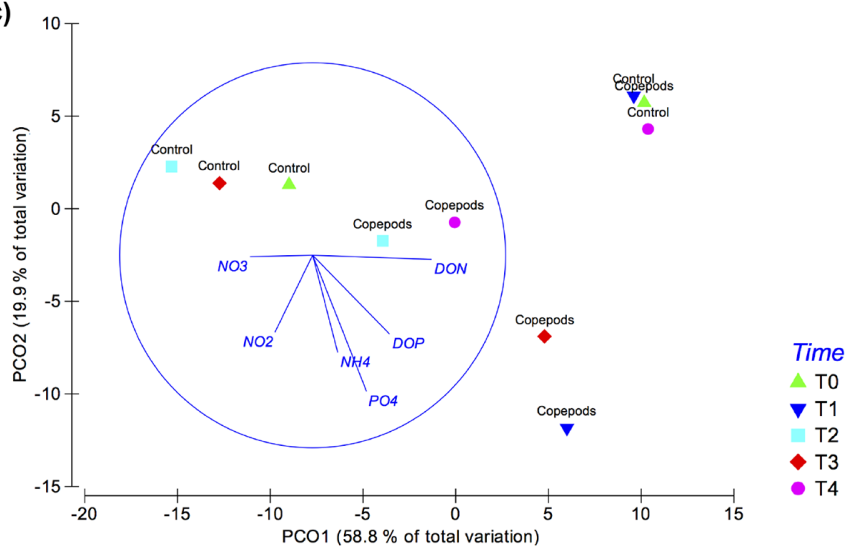

(b)

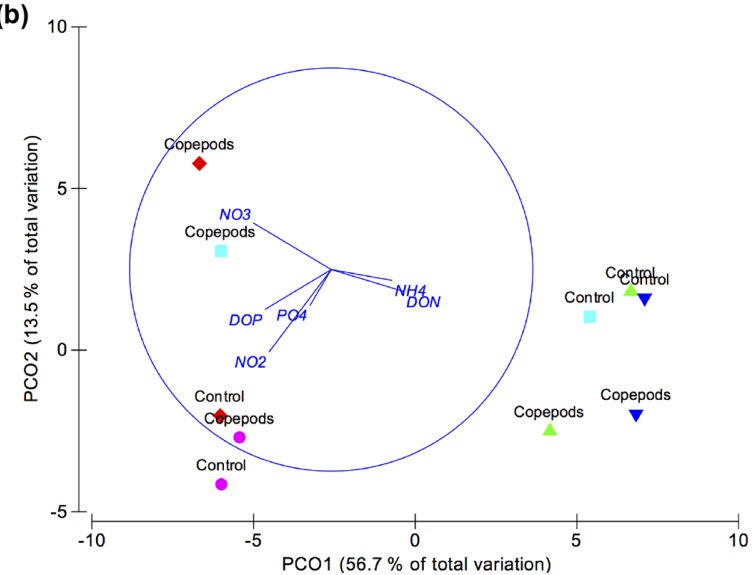

Figure 11. Principal component ordination of treatment with copepods and the control based on Bray-Curtis similarity at order taxonomic level. (a) LD A, (b) LD B and (c) LD C. Vectors indicate the best environmental variables (normalized transformed) correlated with ordinations and vector lengths correspond to the correlation values.

estimate excretion rates for all compounds, since they appear later in the incubation probably modulated by microbial metabolism. Moreover, running an experiment without microbial influence in the control was impossible, since most antimicrobial approaches (e.g., autoclaving, adding antibiotics, filtrating) could have a negative effect on the copepod microbiome and water chemistry, also affecting our results.

\subsection{Changes in bacterial community composition induced by dissolved compounds released by copepods}

During our experiments, we determined the response of microbial community in terms of changes in the abundance and composition of active bacteria. Our experiments showed that the bacterioplankton abundance followed the same patterns of variation in the experiments with copepods and in the controls for each of the three experiments. Also, we found significant differences between treatments (with and without copepods) and between sampling times, except for LD $\mathrm{A}$, in the bacterioplankton community structure (mainly by Gammaproteobacteria and Alphaproteobacteria). A faster re- sponse in Alteromonadales (Gammaproteobacteria) is frequently observed in microcosm studies during incubations, due to their high growth rate and their ability to exploit DOM rapidly when it is available (Alonso-Saez and Gasol, 2007; Fuchs et al., 2000; Landa et al., 2013), which is in accordance with our results. However, the changes in structure associated with the release of dissolved compounds by copepods compared to the controls were not accompanied by an evident increase in bacterioplankton abundance. Several studies have suggested that enrichment experiments tend to enhance the abundance of organisms rarely found in nature, but that have opportunistic and copiotrophic qualities that allow them to rapidly adapt to changes in environmental conditions, outcompeting abundant groups in the field (Nelson and Wear, 2014; Pedler et al., 2014; Logue et al., 2016). In contrast, in the experiment carried out at the LD B station, a substantial decrease in Alteromonadales was observed in the treatment with copepods compared to the control. The higher contribution with time was due to Alphaproteobacteria, for which SAR11 increased their relative abundance $(\sim 8 \%)$ at $1 \mathrm{~h}$ of incubation. SAR 11 was the major constituent of 16 rDNA (in situ) and was also active in accor- 
dance with our 16 rRNA (in situ) readings. SAR11 is the most abundant bacterioplankton in the ocean, is well adapted to low concentration of nutrients and specializes in oxidizing many labile and low-molecular-weight compounds produced by other plankton (Giovannoni, 2017). During our incubations, SAR11 increased their contribution only in the LD B experiment, which coincided with the station with the lowest nutrient concentrations. On the other hand, in the LD $\mathrm{C}$ experiment, an increase in Alteromonadales and Vibrionales was observed. Alteromonadales decreased their contribution in the treatment with copepods at the end of the incubation while increasing their contribution in control. The reverse pattern was observed for SAR11, which increased their contribution at the end of incubation. Based on our experiments, the An Alteromonadales increase coincides with DON available from copepod excretion during the first $2 \mathrm{~h}$ of incubation. Afterwards, at the end of the experiment, nutrients were diminished, and the conditions potentially favored the versatile SAR 11. Peduzzi and Herndl (1992) observed high monomeric carbohydrate concentration and bacterial activity in experiments where copepods were included. Furthermore, these authors observed that bacterial communities living in oligotrophic areas can be efficient in utilizing the newly available substrate source, in accordance with our results.

Bacterial remineralization of DOM derived from copepod metabolism could be a highly efficient mechanism to maintain the nutrients in the upper layer, supporting the phytoplankton and microbial growth. In this sense, the response associated with the different regions of our study suggests that copepods in the MA region could provide DOP as an alternative substrate for phytoplankton and bacterial growth, while the enhanced remineralization by copepods could be more important in the ultra-oligotrophic area of the SG region. However, more studies are necessary to determine the role of zooplankton in the recycling of nutrients in oligotrophic areas. Furthermore, the biogeochemical impact of copepod metabolism may not be limited to the upper layer, as zooplankton can move through the water column by diel vertical migration, promoting the export of dissolved compounds through their metabolism at deeper layers. We conclude that copepod metabolism can provide substantial amounts of nitrogen and phosphorus $\left(\mathrm{NH}_{4}^{+}, \mathrm{DON}, \mathrm{DOP}\right)$, which microbial communities can directly use in a short period of time, enhancing the bacterioplankton remineralization.

Data availability. All data are available at the French insu/cnrs lefe cyber database at the following web address: http://www.obs-vlfr.fr/ proof/php/outpace/outpace.php (last access: 5 October 2018). The Supplement related to this article is available online
at: https://doi.org/10.5194/bg-15-6019-2018-supplement
Author contributions. VV, FC, RE, MP, VM, CF designed the experiment setup. VV and KD carried out the sample collection and incubations experiment on board. VV and VM participated in the molecular analysis. VV treated the data and wrote the paper with contributions from all co-authors.

Competing interests. The authors declare that they have no conflict of interest.

Special issue statement. This article is part of the special issue "Interactions between planktonic organisms and biogeochemical cycles across trophic and $\mathrm{N}_{2}$ fixation gradients in the western tropical South Pacific Ocean: a multidisciplinary approach (OUTPACE experiment)". It is not associated with a conference.

Acknowledgements. This is a contribution of the OUTPACE (Oligotrophy from Ultra-oligoTrophyPACific Experiment) project funded by the French research national agency (ANR-14-CE010007-01), the LEFE-CyBER program (CNRS-INSU), the GOPS program (IRD) and the CNES (BC T23, ZBC 4500048836) and by European FEDER Fund under project 1166-39417. The OUTPACE cruise was managed by $\mathrm{T}$. Moutin and $\mathrm{S}$. Bonnet from the MIO (Mediterranean Institute of Oceanography). The authors thank the crew of the R/V L'Atalante for their outstanding shipboard operation. M. Pujo-Pay (Observatoire Océanologique de Banyuls sur mer), O. Grosso (MIO) and S. Helias (MIO) are thanked for their assistance during the analysis of nutrients. We thank C. Dupouy, T. Moutin and S. Helias for their support in providing Chlorophyll- $a$ and DON-DOP data. This work was supported by the Comisión Nacional de Investigación Científicas y Tecnológicas (CONICYT) through FONDECYT grant nos. 1130511 and 1150891 and Instituto Milenio de Oceanografía (IMO) grant IC120019. Additional support has been provided by FONDAP grants IDEAL and INCAR (15110027 and 15150003, respectively), and CONICYT PIA PFB-31 COPAS Sur austral program. The work was developed in the frame of LIA MORFUN. Valdés and Donoso were funded by the CONICYT Scholarship.

Edited by: Sophie Bonnet

Reviewed by: two anonymous referees

\section{References}

Alonso-Saez, L. and Gasol, J. M.: Seasonal variations in the contributions of different bacterial groups to the uptake of lowmolecular-weight compounds in northwestern Mediterranean coastal waters, Appl. Environ. Microbiol., 73, 3528-3535, 2007.

Aminot, A. and Kérouel, R.: Dosage automatique des nutriments dans les eaux marines: méthodes en flux continu, in: Méthodes d'analyse en milieu marin, Editions Quae, 2007.

Arístegui, J., Duarte, C. M., Reche, I., and GómezPinchetti, J. L.: Krill Excretion Boosts Microbial Activity in the Southern Ocean, PLoS One, 9, e89391, https://doi.org/10.1371/journal.pone.0089391, 2014. 
Bidigare, R.: Nitrogen excretion by marine zooplankton, in: Nitrogen in the marine environment, edited by: Carpenter, E. and Capone, D., 385-409, Academic Press, 1983.

Bonnet, S., Caffin, M., Berthelot, H., and Moutin, T.: Hot spot of $\mathrm{N}_{2}$ fixation in the western tropical South Pacific pleads for a spatial decoupling between $\mathrm{N}_{2}$ fixation and denitrification, P. Natl. Acad. Sci. USA, 114, E2800-E2801, 2017.

Caffin, M., Moutin, T., Foster, R. A., Bouruet-Aubertot, P., Doglioli, A. M., Berthelot, H., Guieu, C., Grosso, O., Helias-Nunige, S., Leblond, N., Gimenez, A., Petrenko, A. A., de Verneil, A., and Bonnet, $\mathrm{S}$.: $\mathrm{N}_{2}$ fixation as a dominant new $\mathrm{N}$ source in the western tropical South Pacific Ocean (OUTPACE cruise), Biogeosciences, 15, 2565-2585, https://doi.org/10.5194/bg-152565-2018, 2018.

Campbell, B. J. and Kirchman, D. L.: Bacterial diversity, community structure and potential growth rates along an estuarine salinity gradient, ISME J., 7, 210-220, 2013.

Carlotti, F., Pagano, M., Guilloux, L., Donoso, K., Valdés, V., and Hunt, B. P. V.: Mesozooplankton structure and functioning in the western tropical South Pacific along the $20^{\circ}$ parallel south during the OUTPACE survey (February-April 2015), Biogeosciences Discuss., https://doi.org/10.5194/bg-2017-573, in review, 2018.

Carpenter, E. J., Subramaniam, A., and Capone, D. G.: Biomass and primary productivity of the cyanobacterium Trichodesmium spp. in the tropical N Atlantic Ocean, Deep-Sea Res., 51, 173-203, 2004.

Conover, R. J. and Gustavson, K. R.: Sources of urea in arctic seas: zooplankton metabolism, Mar. Ecol. Prog. Ser., 179, 41r54, https://doi.org/10.3354/meps179041, 1999.

de Verneil, A., Rousselet, L., Doglioli, A. M., Petrenko, A. A., Maes, C., Bouruet-Aubertot, P., and Moutin, T.: OUTPACE long duration stations: physical variability, context of biogeochemical sampling, and evaluation of sampling strategy, Biogeosciences, 15, 2125-2147, https://doi.org/10.5194/bg-15-2125-2018, 2018.

Dupouy, C., Frouin, R., Tedetti, M., Maillard, M., Rodier, M., Lombard, F., Guidi, L., Picheral, M., Neveux, J., Duhamel, S., Charrière, B., and Sempéré, R.: Diazotrophic Trichodesmium impact on UV-Vis radiance and pigment composition in the western tropical South Pacific, Biogeosciences, 15, 5249-5269, https://doi.org/10.5194/bg-15-5249-2018, 2018.

Edgar, R. C., Haas, B. J., Clemente, J. C., Quince, C., and Knight, R.: UCHIME improves sensitivity and speed of chimera detection, Bioinformatics, 27, 2194-2200, https://doi.org/10.1093/bioinformatics/btr381, 2011.

Eppley, R. W., Renger, E. H., Venrick, E. L., and Mullin, M. M.: A study of plankton dynamics and nutrient cycling in the central gyre of the North Pacific Ocean, Limnol. Oceanogr., 18, 534551, 1973.

Fuchs, B. M., Zubkov, M. V., Sahm, K., and Amann, R.: Changes in community composition during dilution cultures of marine bacterioplankton as assessed by flow cytometric and molecular biological techniques, Environ. Microbiol., 2, 191-201, 2000.

Giovannoni, S. J.: SAR11 Bacteria: The Most Abundant Plankton in the Oceans, Annu. Rev. Mar. Sci., 9, 231-255, 2017.

Hasegawa, T., Koike, I., and Mukai, H.: Dissolved organic nitrogen dynamics in coastal waters and the effect of copepods, J. Exp. Mar. Biol. Ecol., 244, 219-238, 2000.
Hernández-León, S., Fraga, C., and Ikeda, T.: A global estimation of mesozooplankton ammonium excretion in the open ocean, J. Plankton Res., 30, 577-585, 2008.

Holmes, R., Aminot, A., Kérouel, R., Hooker, B., and Peterson, B.: A simple and precise method for measuring ammonium in marine and freshwater ecosystems, Can. J. Fish. Aquat. Sci., 56, 1801-1808, 1999.

Ikeda, T., Kanno, Y., Ozaki, K., and Shinada, A.: Metabolic rates of epipelagic marine copepods as a function of body mass and temperature, Mar. Biol., 139, 587-596, 2001.

Isla, J. A., Llope, M., and Andón, R.: Size-fractionated mesozooplankton biomass, metabolism and grazing along a $50 \mathrm{~N}-30 \mathrm{~S}$ transect of the Atlantic Ocean, J. Plankton Res., 26, 1301-1313, 2004.

Johannes, R. E.: Uptake and release of dissolved organic phosphorus by representatives of a coastal marine ecosystem, Limnol. Oceangr., 9, 224-234, 1964.

Karl, D. M., Letelier, R. M., Dore, J. E., Christian, J., and Hebel, D.: The role of nitrogen fixation in biogeochemical cycling in the subtropical North Pacific Ocean, Nature, 388, 533-538, 1997.

Landa, M., Cottrell, M., Kirchman, D., Blain, S., and Obernosterer, I.: Changes in bacterial diversity in response to dissolved organic matter supply in a continuous culture experiment, Aquat. Microb. Ecol., 69, 157-168, 2013.

Levipan, H. A., Molina, V., and Fernandez, C.: Nitrospina-like bacteria are the main drivers of nitrite oxidation in the seasonal upwelling area of the Eastern South Pacific (Central Chile $\sim 36^{\circ} \mathrm{S}$ ): Nitrite-oxidizing bacteria in the seasonal upwelling system off Concepcion, Environ. Microbiol. Rep., 6, 565-573, 2014.

Logue, J. B., Stedmon, C. A., Kellerman A. M., Nielsen, N. J., Andersson, A. F., Laudon, H., Lindström E. S., and Kritzberg, E. S.: Experimental insights into the importance of aquatic bacterial community composition to the degradation of dissolved organic matter, ISME J., 10, 533-545, https://doi.org/10.1038/ismej.2015.131, 2016.

Marie, D., Partensky, F., Jacquet, S., and Vaulot, D.: Enumeration and cell cycle analysis of natural populations of marine picoplankton by flow cytometry using the nucleic acid stain SYBR Green I, Appl. Environ. Microbiol., 63, 186-193, 1997.

Miller, C. A. and Glibert, P. M.: Nitrogen excretion by the calanoid copepod Acartia tonsa: results of mesocosm experiments, J. Plankton Res., 20, 1767-1780, 1998.

Miller, C. A. and Roman, M. R.: Effects of food nitrogen content and concentration on the forms of nitrogen excreted by the calanoid copepod, Acartia tonsa, J. Exp. Mar. Biol. Ecol., 359, 11-17, 2008.

Møller, E. F.: Sloppy feeding in marine copepods: prey-sizedependent production of dissolved organic carbon, J. Plankton Res., 27, 27-35, 2004.

Møller, E. F.: Production of dissolved organic carbon by sloppy feeding in the copepods Acartia tonsa, Centropages typicus, and Temora longicornis, Limnol. Oceanogr., 52, 79-84, 2007.

Moutin, T., Karl, D. M., Duhamel, S., Rimmelin, P., Raimbault, P., Van Mooy, B. A. S., and Claustre, H.: Phosphate availability and the ultimate control of new nitrogen input by nitrogen fixation in the tropical Pacific Ocean, Biogeosciences, 5, 95-109, https://doi.org/10.5194/bg-5-95-2008, 2008.

Moutin, T., Doglioli, A. M., de Verneil, A., and Bonnet, S.: Preface: The Oligotrophy to the UlTra-oligotrophy PACific Ex- 
periment (OUTPACE cruise, 18 February to 3 April 2015), Biogeosciences, 14, 3207-3220, https://doi.org/10.5194/bg-143207-2017, 2017.

Moutin, T., Wagener, T., Caffin, M., Fumenia, A., Gimenez, A., Baklouti, M., Bouruet-Aubertot, P., Pujo-Pay, M., Leblanc, K., Lefevre, D., Helias Nunige, S., Leblond, N., Grosso, O., and de Verneil, A.: Nutrient availability and the ultimate control of the biological carbon pump in the western tropical South Pacific Ocean, Biogeosciences, 15, 2961-2989, https://doi.org/10.5194/bg-15-2961-2018, 2018.

Mulholland, M. R., Floge, S., Carpenter, E. J., and Capone, D. G.: Phosphorus dynamics in cultures and natural populations of Trichodesmium spp, Mar. Ecol. Prog. Ser., 239, 45-55, 2002.

Nelson, C. E. and Wear, E. K.: Microbial diversity and the lability of dissolved organic carbon, P. Natl. Acad. Sci. USA, 111, 71667167, https://doi.org/10.1073/pnas.1405751111, 2014.

Pedler, B. E., Aluwihare, L. I., and Azam, F.: Single bacterial strain capable of significant contribution to carbon cycling in the surface ocean, P. Natl. Acad. Sci. USA, 111, 7202-7207, https://doi.org/10.1073/pnas.1401887111, 2014.

Pedrós-Alió, C.: The Rare Bacterial Biosphere, Annu. Rev. Mar. Sci., 4, 449-466, 2012.

Peduzzi, P. and Herndl, G. J.: Zooplankton activity fuelling the microbial loop: differential growth response of bacteria from oligotrophic and eutrophic waters, Limnol. Oceanogr., 37, 10871092, 1992.

Pérez-Aragón, M., Fernandez, C., and Escribano, R.: Nitrogen excretion by mesozooplankton in a coastal upwelling area: Seasonal trends and implications for biological production, J. Exp. Mar. Biol. Ecol., 406, 116-124, 2011.

Polovina, J. J., Howell, E. A., and Abecassis, M.: Ocean's least productive waters are expanding, Geophys. Res. Lett., 35, L03618, https://doi.org/10.1029/2007GL031745, 2008.

Pujo-Pay, M. and Raimbault, P.: Improvement of the wet-oxidation procedure for simultaneous determination of particulate organic nitrogen and phosphorus collected on filters, Mar. Ecol.-Prog. Ser., 105, 203-203, 1994.

Quast, C., Pruesse, E., Yilmaz, P., Gerken, J., Schweer, T., Yarza, P., Peplies, J., and Glöckner, F. O.: The SILVA ribosomal RNA gene database project: improved data processing and web-based tools, Nucleic Acids Res., 41, D590-D596, https://doi.org/10.1093/nar/gks1219, 2013.

Raimbault, P. and Garcia, N.: Evidence for efficient regenerated production and dinitrogen fixation in nitrogen-deficient waters of the South Pacific Ocean: impact on new and export production estimates, Biogeosciences, 5, 323-338, https://doi.org/10.5194/bg-5-323-2008, 2008.

Richardot, M., Debroas, D., Thouvenot, A., Sargos, D., Berthon, J., and Dévaux, J.: Influence of cladoceran grazing activity on dissolved organic matter, enzymatic hydrolysis and bacterial growth, J. Plankton Res., 23, 1249-1261, 2001.

Saba, G., Steinberg, D., and Bronk, D.: Effects of diet on release of dissolved organic and inorganic nutrients by the copepod Acartia tonsa, Mar. Ecol. Prog. Ser., 386, 147-161, 2009.
Saba, G. K., Steinberg, D. K., and Bronk, D. A.: The relative importance of sloppy feeding, excretion, and fecal pellet leaching in the release of dissolved carbon and nitrogen by Acartia tonsa copepods, J. Exp. Mar. Biol. Ecol., 404, 47-56, 2011.

Sarmento, H., Romera-Castillo, C., Lindh, M., Pinhassi, J., Sala, M. M., Gasol, J. M., Marrase, C., and Taylor, G. T.: Phytoplankton species-specific release of dissolved free amino acids and their selective consumption by bacteria, Limnol. Oceanogr., 58, 1123 1135, 2013.

Satomi, M. and Pomeroy, L. R.: Respiration and Phosphorus Excretion in Some Marine Populations, Ecology, 46, 877-881, 1965.

Schloss, P. D., Westcott, S. L., Ryabin, T., Hall, J. R., Hartmann, M., Hollister, E. B., Lesniewski, R. A., Oakley, B. B., Parks, D. H., Robinson, C. J., Sahl, J. W., Stres, B., Thallinger, G. G., Horn, D. J. V., and Weber, C. F.: Introducing mothur: Open-Source, Platform-Independent, Community-Supported Software for Describing and Comparing Microbial Communities, Appl. Environ. Microbiol., 75, 7537-7541, 2009.

Sipler, R. E. and Bronk, D. A.: Dynamics of dissolved organic nitrogen, in: Biogeochemestry of marine dissolved organic matter, edited by: Hansell, D. A. and Carlson, C. A., 2nd edition, 128213, Academic, 2014.

Smith, S. L. and Whitledge, T. E.: The role of zooplankton in the regeneration of nitrogen in a coastal upwelling system off northwest Africa, Deep-Sea Res., 24, 49-56, 1977.

Steinberg, D. K. and Landry, M. R.: Zooplankton and the Ocean Carbon Cycle, Annu. Rev. Mar. Sci., 9, 413-444, 2017.

Steinberg, D. K. and Saba G. K..: Nitrogen consumption and metabolism in marine zooplankton, in: Nitrogen in the marine environment, edited by: Capone, D. G., 1135-1196, Academic, 2008.

Steinberg, D. K., Carlson, C. A., Bates, N. R., Goldthwait, S. A., Madin, L. P., and Michaels, A. F.: Zooplankton vertical migration and the active transport of dissolved organic and inorganic carbon in the Sargasso Sea, Deep-Sea Res., 47, 137-158, 2000.

Steinberg, D. K., Goldthwait, S. A., and Hansell, D. A.: Zooplankton vertical migration and the active transport of dissolved organic and inorganic nitrogen in the Sargasso Sea, Deep Sea Res., 49, 1445-1461, 2002.

Titelman, J., Riemann, L., Holmfeldt, K., and Nilsen, T.: Copepod feeding stimulates bacterioplankton activities in a low phosphorus system, Aquat. Biol., 2, 131-141, 2008.

Valdés, V., Fernandez, C., Molina, V., and Escribano, R.: Nitrogen excretion by copepods and its effect on ammonia-oxidizing communities from a coastal upwelling zone, Limnol. Oceanogr., 63, 178-294, https://doi.org/10.1002/lno.10629, 2017a.

Valdés, V. P., Fernandez, C., Molina, V., Escribano, R., and Joux, F.: Dissolved compounds excreted by copepods reshape the active marine bacterioplankton community composition, Front. Mar. Sci., 4, 343, https://doi.org/10.3389/fmars.2017.0034, 2017b.

Vargas, C. A., Cuevas, L. A., González, H. E., and Daneri, G.: Bacterial growth response to copepod grazing in aquatic ecosystems, J. Mar. Biol. Assoc. UK, 87, 667-674, 2007. 